\title{
Transient gene expression and total flavonoids production in the electroporated licorice Glycyrrhiza glabra L. suspension protoplasts
}

\author{
P. G. Kovalenko \\ Institute of Molecular Biology and Genetics National Academy of Sciences of Ukraine \\ Zabolotnoho str. 150 , Kyiv, 03143 , Ukraine \\ E-mail:omg@imbg.org.ua
}

\begin{abstract}
The bacterial chloramphenicol acetyltransferase (CAT) gene was expressed in licorice G. glabra $L$. suspension protoplasts by electroporation after introduction of the chimeric plasmid pDNt23-CaMV35Snos-cat ( $\rho D N t 23$-root-specific and CaMV $35 S$ promoters, nopaline synthase nos-terminator, and selectable NPT-II gene). Maximum of CAT activity in the licorice protoplasts was observed in $50 \mathrm{~h}$ after electroporation. Together with recent advances in the cell isolation and electroporation procedures, this system allows to study expression of the root-specific promoter introduced into the licorice cells. The level of total flavonoids production in 4 weeks culture was tested in the electroporated cell lines. Additionally, these electroporated cells were treated by elicitors (yeast extract and fungal bioextract). The total flavonoids production increased by $2-5$ times in comparison with the non-electroporated licorice cells.
\end{abstract}

Introduction. At present, in biotechnology great attention is paid to plant tissue cultures, because the plant cells are able to synthesize specific compounds, especially various important secondary metabolites which are useful as medicines and food additives. Although lots of attempts have been made on plant cell suspension culture as a source of the important metabolites. Dedifferentiated plant cells are heterogeneous in the genetic composition and the contents of economically important metabolites are often lower than in donor plants.

The suspension cells can grow more rapidly than original field plants, which makes it possible to increase the expectable productivity of in vitro culture. The productivity can be also enhanced by optimization of cultivation conditions, cell selection and genetic transformation. Recent advances in recombinant DNA technology allow to generate new transgenic plant species that is of high importance for the pharmaceutical industry and new drug design. It is necessary to have a system of genetic transformation that is simple and effective.

Electroporation is widely used to produce stable

(C) P. G. KOVALENKO, 2004 genetic transformation in both prokaryotic and cukaryotic organisms. It is used extensively as an efficient method for studing the transient gene expression.

Suspension protoplasts electroporation allows to introduce foreign DNA into a great variety of the plant species. To establish a genctic transformation system via electroporation, it is necessary to have an cell competent for the electroporation process, and an in vitro culture system, which permits a high frequency of regeneration. In plants, the major limitation of recovering stable transformants by protoplasts electroporation is the requirement for an efficient protoplast-to-plant regeneration scheme. The effects of an electric field on cell walls are still unknown more fully. Biological membranes are composed of phospholipids, amphipatic molecules having a hydrophilic head group attached to a hydrophobic tail. They can be polarized in electric fields. Electric pulses raise the transmembrane potential, promoting transient pore formation due to the increased dipole moment of the hydrophilic lipid heads, allowing charged macromolecules to migrate through the pores and eventually reach the nucleus where they can promote genetic transformation.

The roots of European licorice (G. glabra L., 
Leguminosae, tribe Astragalaceae) and other members of this pharmacologically important genus contain many flavonoids. Flavonoids represent a large group of phenolic secondary metabolites widespread in plants and involved in different plant functions. Some flavonoids like liquiritin, isoliquiritin, liquiritigen, lucuraside and others are known to possess antiallergic, anti-inflammatory, anti-viral and anti-carcinogenic activities [1-4]. However, very often the biosynthetic potential of the callus mass and suspension culture can be decreased in comparison with the original plant tissue [5].

As reported in our previous papers $[9,15]$, the plant DNA fragments with transcription promoted activity were selected from the pool of random tobacco nuclear DNA fragments, and one of them (pDNt23) was shown to have the root-specific expression in transgenic plants. The chimeric plasmid pDNt2335SCaMV-CAT-nos-3 (pDNt23-root specific promoter, nos-nopaline synthase terminator and had the selectable gene as neomycin phosphotransferase IINPT-II) was used in our experiments with the electroporation of the licorice suspension protoplasts. In this report we optimized electroporation efficiency to study the activity of the reporter chloramphenicol acetyltransferase (CAT) gene in electroporated licorice cells and the total flavonoids production from these electroporated cells. The transient expression of the reporter CAT gene under the control of cauliflower mosaic virus promoter has been demonstrated to be a powerful tool to study the introduction of exogenous DNA into plant protoplasts [6]. The testing of marker genes, usually under the $35 \mathrm{~S}$ promoter control, is also of great interest for the licorice biotechnology. In this casc the CAT assay was used as a sensitive method to detect the functional activity of the root-specific (pDNt23) promoter sequences in electroporated licorice cells. Second, the successful genetic manipulation with licorice suspension cells depends significantly from the physiological conditions of the freshly isolated protoplasts.

However, up to now there is limited information on the relationship between electroporation conditions and the CAT expression in the licorice protoplasts cells. The electroporation method used by us, included the rectangular (RC) pulse generating system and the capacitor discharge to deliver pulses of exponentially decaying voltage.

The general aim of this work was to characterize the factors affecting the CAT expression in the electroporated licorice cells, while using the $\mathrm{RC}$ pulse generating system. First, we have optimized electroporation efficiency to study the activity of the reporter CAT gene in electroporated licorice cells.
The CAT expression is shown to be influenced by interactions between electrical parameters of the system and physiological state of the isolated cells. Second, these electroporated licorice cells were tested for the total flavonoids production. Third, electroporated cell lines have been treated by elicitors and which were found to increase the total flavonoids level (2-5 fold) in comparison with the control (i. e. non-electroporated and non-elicitated) licorice cells.

Materials and Methods. Plant material and cell culture. The callus culture obtaincd from seeds, stolon and root of licorice, G. glabra L., was used for subsequent initiation of a cell suspension culture. The callus was cultured in the modified MS (MurashigeSkoog) [7] medium with addition of $0.2-1.0 \mathrm{mg} / 1$ benzyladenin (BA), $0.5-5.0 \mathrm{mg} / \mathrm{l}$ naphthalen acetic acid (NAA), $0.9 \%$ agar. Approximately $67 \%$ of the explants, used in this work, initiated callus growth during 3 weeks. Growth of callus was slightly better at $\mathrm{pH} 5.7-6.0$. The well-growing callus cell lines were used for further experiments in the modified liquid MS medium with addition of $0.2-2.0 \mathrm{mg} / 1 \mathrm{BA}$, $0.2-2.0 \mathrm{mg} / 1 \mathrm{NAA}$. In this medium, cell suspensions, consisted of clumps of $10-30$ mostly spherical cells, were produced. The cultures werc agitated in a reciprocal shaker (110 agitation $/ \mathrm{min}$ ) in the dark at $25{ }^{\circ} \mathrm{C}$, and subcultured at 24 days intervals. The 3 months old actively growing suspension cells, were sieved using stainless steel mesh $(500-1000 \mu \mathrm{m}$ opening) to exclude large cell clusters and washed. Cells were then treated for $9 \mathrm{~h}$ in incubation buffer containing $0.5 \%$ cellulase R-10 «Onozuka» (Yakult Honsha Co, Japan), $0.5 \%$ macerozyme R-10 ( Sigma Chemical» Co, USA), and $0.3 \%$ dricelase («Sigma Chemical») dissolved in $0.6 \mathrm{M}$ mannitol, with MS salts. During the enzymes treatment, cells were incubated in the dark at $25^{\circ} \mathrm{C}$. Following enzymes treatment, protoplasts were washed once with $10 \mathrm{ml}$ of sucrose-mannitol gradient and followed by three washes with electroporation buffer. The protoplasis density was determined by counting on a haemocy tometer and their viability was measured by the exclusion of phenosafranine («Aldrich», USA) according to Widholm [8]. Typical yield was $(0.7-1.0) \cdot 10^{7}$ of protoplasts per $1 \mathrm{~g}$ with viability of $70-80 \%$.

Electroporation. The electroporator Invitrogen-4 was used for electroporation of the licorice suspension protoplasts. This electroporator has the capacitor discharge system (capacitance from 50 to $200 \mu \mathrm{F}$ ).

The protoplasts of density from $4 \cdot 10^{5}$ to $10^{6}$ cells per $1 \mathrm{ml}$ were electroporated in buffer: $20 \mathrm{mM} \mathrm{KCl}$, $6 \mathrm{mM} \mathrm{MgCl} \mathrm{Mg}_{2}, 0.6 \mathrm{M}$ sorbitol, $\mathrm{pH} 6.0$, and then mixed with plasmid DNA and carrier DNA. $340 \mu \mathrm{l}$ of protoplasts suspension in a cylindrical chamber (tem- 
perature $4{ }^{\circ} \mathrm{C}$, resistance $1.7 \mathrm{k} \Omega$ ) were electroporated using stainless steel electrodes, placed $1 \mathrm{~cm}$ apart.

For the optimization of the electroporation process, the protoplasts were subjected to three electrical pulses (RC pulse duration $80 \mathrm{~ms}$ at $0-350 \mathrm{~V} / \mathrm{cm}$, with $30 \mathrm{~s}$ intervals between the pulses). After the electroporation, the protoplasts samples were kept on ice for $8 \mathrm{~min}$ to extend the open-pore status [14]. Then the protoplasts were diluted with an equal volume of the modified MS medium and cultured at $25^{\circ} \mathrm{C}$ in darkness.

Plasmid construction. The pDNt-35SCaMVCAT-nos-3'-NPT-II gene construction was obtained from the Department of Bioengineering, Institute of Bioorganical and Oil Chemistry NAS of Ukraine (Kyiv) and used for the direct gene transfer into the licorice protoplasts by electroporation [9].

Both linearized and supercoiled forms of the plasmid were used in the experiments.

The plasmids were propagated in Escherichia coli and purified according to the standard protocol. The plasmid DNA was linearized by means of digestion with appropriate restriction enzymes. After phenolchloroform extraction and ethanol precipitation DNA was resuspended in water under sterile conditions. Non-linearized plasmid DNA was treated in the same way as linearized DNA except for the digestion step. DNA concentration was measured by spectrophotometry at $260 \mathrm{~nm}$. The carrier DNA (calf thymus DNA, «Sigma Chemical») in concentrations of 0,20 , 50 or $150 \mu \mathrm{g} / \mathrm{ml}$ was added. The plasmid was sterilized by ethanol precipitation and dissolved in the electroporation buffer.

Protoplasts viability and CAT assay. After 48$52 \mathrm{~h}$ of cultivation the number of survived protoplasts was counted in ten random fields using the light field microscopy («LOMO», Russia). Dead protoplasts were clearly distinguishable and appeared as condensed and twisted structures. The protoplasts viability was also confirmed by staining with fluorescein diacetate [8]. The study on CAT activity was performed in general as described by Gorman et al. [10].

Bricfly, protoplasts $\left(3 \cdot 10^{5}\right.$ cells per $\left.1 \mathrm{ml}\right)$ were collected by centrifugation and the pellets were resuspended in $500 \mu \mathrm{l}$ of buffer $(0.225 \mathrm{M}$ Tricine, $\mathrm{pH} 7.8$, $5 \mathrm{mM}$ phenylmethyl sulphonyl fluoride and $5 \mathrm{mM}$ EDTA). The extracts were clarified by centrifugation for $10 \mathrm{~min}$, and the supernatant was transferred to a fresh tube and heated for $10 \mathrm{~min}$ at $65^{\circ} \mathrm{C}$. Acetyl$\mathrm{CoA}$ (final concentration of $1 \mathrm{mM}$ ) and ${ }^{14} \mathrm{C}$-chloramphenicol $\left(1 \mu \mathrm{Ci}, 60 \mu \mathrm{Ci} \cdot \mathrm{mmol}^{-1}\right)$ were added and the reaction was allowed to proceed for $1 \mathrm{~h}$ at room temperature being terminated by the addition of 10 volumes of ethyl acetate. 0.5 unit of commercial CAT
(«Sigma Chemical») was used as a control. After clarification by centrifugation the pellet was dried, redissolved in $30 \mu \mathrm{l}$ of ethyl acetate and submitted to ascending chromatography in chloroform/methanol $(95: 5 \mathrm{v} / \mathrm{v})$ on silicagel plates. Separated spots of ${ }^{14} \mathrm{C}$-chloramphenicol and its acetylated forms were identified by the autoradiography percent conversion on TASMA $(\mathrm{Ru})$ film after 7 days of exposure. The results are expressed as percent conversion of chloramphenicol to the acetylated forms. The calibration experiments with commercial CAT showed that there was a linear relationship between the enzyme amount (up to 1 unit) and the percent conversion obtained under the conditions used (1 unit gave $93 \%$ conversion).

The CAT activity in «negative controls» was determined either after incubation of the protoplasts with the plasmid and carrier DNA without electroporation, or after electroporation in the presence of carrier, but not the plasmid DNA, as described by Jones et al. [11].

Selection of transformants. After electroporation, cells were diluted with the fresh modified liquid MS medium with $0.2-0.5 \mathrm{mg} / 1 \mathrm{BA}, 0.5-1.0 \mathrm{mg} / 1 \mathrm{NAA}$, $0.05 \mathrm{mg} / 1$ 2.4D (dichlorophenoxyacetic acid), and stored for 2 days at $22{ }^{\circ} \mathrm{C}$ in the dark. After this time, the electroporated protoplasts were transferred to a fresh modified MS medium supplemented with $100 \mathrm{mg} / 1 \mathrm{kanamycin}$ sulfate and cultivation at $25^{\circ} \mathrm{C}$ in the dark at 7-days. The fresh medium with the half reduce concentration of kanamycin sulphate were used on the every new passage. Well-growing suspension protoplasts were selected to produce lines of kanamycin-resistant cell aggregates and which were used as a source for the total flavonoids production. Non-electroporated (control) licorice protoplasts were cultured on the modified MS medium without kanamycin sulphate.

Production of flavonoids by electroporated licorice cells. Concentration of the accumulated flavonoids in the electroporated licorice suspension cells was analyzed after 4 weeks in culture using spectrophotometric analysis («Specord UV», Germany) at $295 \mathrm{~nm}$.

The flavonoids were extracted with ten volumes of hot water $\left(90^{\circ} \mathrm{C}\right)$ over the harvested cells for $3 \mathrm{~h}$. The calibration curve was constructed for liquiritigenin as described in [12] and modified in [13]. Al] the experiments were triplicated and average values were analysed.

Results and Discussion. Electroporation of the licorice suspension protoplasts $G$, glabra with the pDNt-35SCaMV-CAT-nos-3'-NPT-II plasmid resulted in transient expression of the CAT reporter gene 
in the electroporated cells as an indicator of successful plasmid delivery. In control, the licorice protoplasts were electroporated in the absence of plasmid DNA. The reporter CAT gene expression in these cells was never observed.

For the obtain the optimal level by the CAT assay in the electroporated licorice cells, the electrical parameters were optimized. It has been shown earlier that the electroporation can be successfully used for the variety of protoplasts transformation. Two electroporation systems are commonly in use: based either on low-voltage/long pulses or on high-voltage/short pulses [14]. We used the square-wave pulse generator with capacitor discharge system, which delivers exponentially decaying voltage pulses. The typical values for the low-voltage/long pulse method are 200-450 $\mathrm{V} / \mathrm{cm}$ and $10-90 \mathrm{~ms}$ (exponential decay) [15]. This method results in obtaining stably transformed cell lines and high cell viability after electroporation [15, 16 ]. The optimal voltage and time constant depend on the protoplast diameter, the plasmid concentration and form, cell density and physiological properties of the isolated protoplasts.

Electroporation, therefore, requires a balance between conditions, which either lead to the increase in membrane permeability or result in membrane breakdown and loss of protoplast viability. The mechanisms of the electrically induced permeability were based on specific changes in membranes. However, the processes of lipid bilayer configuration and the penetration of cell surface adsorbed plasmid DNA into the cell interior are not well known yet. Transient membrane pores are caused by an increase in the dipole moment of hydrophilic phospholipid heads, which move in the same direction as the applied electric field and provoke highly localized dielectric breakages in membrane structure [17].

Our initial experiments were focused on the establishing of licorice cell lines (suspension protoplasts) and determination of effective voltage for the transient CAT gene expression. The results obtained correspond to those described by other authors [11] where transient CAT activity was shown to depend on the balance between conditions favoring membrane permeabilization and those leading to irreversible membrane breakdown.

Using the capacitor discharge system, Fromm et al. have found that the CAT activity in the carrot protoplasts and their survival after electroporation may be influenced by the salt composition in the electroporation buffer [18]. The intensity of electrical pulse (voltage, pulse length) and pulse number required for the transformation of protoplasts were inversely proportional to the protoplast diameter [22].

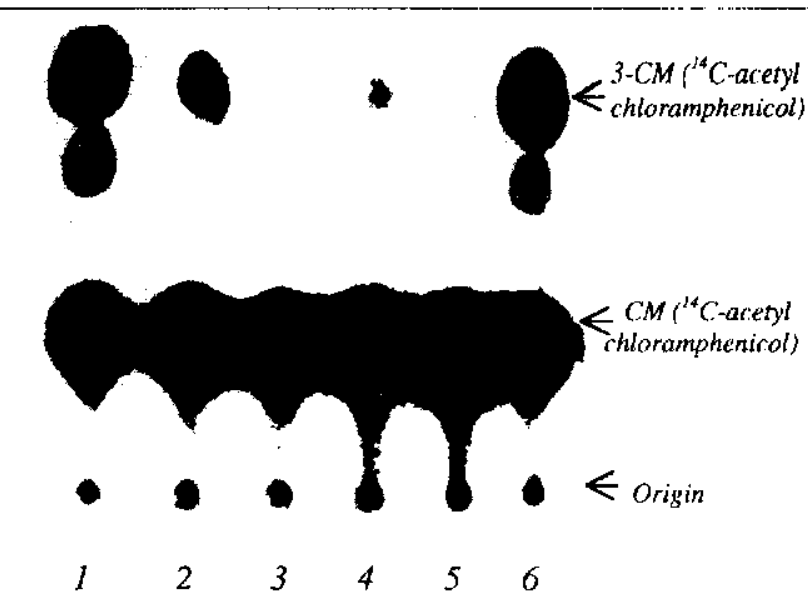

Transient CAT activity in $G$. glabra suspension protoplasts electroporated with plasmid $p D N t 23-35 S-n o s$ in linear form. Lane $I$ and 6 - controls: CAT assay with commercial enzyme; voltage not applied and viability was $64 \pm 1.2 \% ; 2-250 \mathrm{~V} / \mathrm{cm}$ and $38.5 \pm 1.3$ $\%$ viability; $3-400 \mathrm{~V} / \mathrm{cm}$ and viability $9.4 \pm 1.5 \% ; 4-350 \mathrm{~V} / \mathrm{cm}$ and viability were $27.2 \pm 3.3 \%$

The average cell size of the licorice suspension protoplasts used in our experiments was $29-36 \mu \mathrm{M}$, the protoplasts being isolated from exponentially dividing suspension cells ( $3-4$ days culture). This population of suspension cells obviously contains the largest proportion of mitotic cells, and freshly isolated protoplasts appeared to be the most suitable for the electroporation. The older $(5-7$ days) licorice suspension cells do not divide synchronously, therefore their use for electroporation is insufficient. It has been shown previously that the suspension culture protoplasts can be permeabilised at a range of voltage, presumably because of the cell size heterogeneity in the population. The voltage required for membrane breakdown depends on the cell size [11], the larger protoplasts being permeabilized at lower field strengths, while the smaller cells at higher field strengths.

Viability of the electroporated and non-electroporated licorice suspension protoplasts was $38.5 \pm 1.3 \%$ at $250 \mathrm{~V} / \mathrm{cm} ; 27.2 \pm 3.3 \%$ at $350 \mathrm{~V} / \mathrm{cm}, 64 \pm 1.2 \%$ in control (non-electroporated cells) (Figure).

To achieve better viability of electroporated licorice protoplasts and to increase the flavonoid production by electroporated cells, we have transferred the electroporated cells to the fresh modified MS medium with addition of phytohormones and bioregulators. Maximum effect of the field strength on reporter CAT gene expression of pDNt-CaMV35S-nos-NPT-II plasmid was observed within $50 \mathrm{~h}$ after electroporation.

The optimal field strength was: $300 \mathrm{~V} / \mathrm{cm}$ with $30 \mathrm{~s}$ intervals between 3 pulses ( $\mathrm{RC}$ pulse duration $=$ $80 \mathrm{~ms}$ ), and with the constant capacitance $95 \mu \mathrm{F}$. This 
Table I

Transient CAT activity in licorice G. glabra L. suspension protoplasts electroporated with various forms of pDNt-CaMV35S-nos-NPT-II

\begin{tabular}{|c|c|c|c|c|}
\hline DNA forms & Plesmids, $\mu \mathrm{g} / \mathrm{m}$ l & Number of electroporation & Pcoloplasts, cells/ml* & $\operatorname{cpCM}$ total $\left(10^{4}\right)^{* *}$ \\
\hline Linearing & 50 & 3 & 37 & 29 \\
\hline Linearing & 100 & 3 & 44 & 72 \\
\hline Supercoiled & 50 & 3 & 35 & 0.6 \\
\hline Supercoiled & 100 & 3 & 39 & 31 \\
\hline
\end{tabular}

*\% of surviving protoplasts, viability of non-electroporated controls was: $62.8 \pm 17.6 \%$; **count of cpm-chloramphenicol (CM). CAT enzyme control gave $92.6 \pm 6.4 \% \mathrm{CM}$, per $10^{4}$ surviving cells; non-electroporated control was: $0.003 \%$, per $10^{4}$ surviving licorice cells

Table 2

Effect of the carrier DNA on the CAT activity in the licorice suspension protoplasts

\begin{tabular}{c|c|c}
\hline Carrier $\mathrm{DNA}, \mu \mathrm{g} / \mathrm{mi}$ & Plasmid, $\mu \mathrm{g} / \mathrm{ml}^{*}$ & CM 10ta ${ }^{* *}$ \\
\hline 0 & 0 & 0.3 \\
20 & 0 & 0.3 \\
50 & 0 & 0.2 \\
0 & 100 & 67 \\
20 & 100 & 62 \\
50 & 100 & 73 \\
20 & 50 & 26 \\
50 & 50 & 23 \\
100 & 50 & 28 \\
150 & 100 & 64
\end{tabular}

${ }^{*}$ pDNt35S-nos-NPT-II; ** count of cpm-chloramphenicol (CM). The field strength was constant as $350 \mathrm{~V} / \mathrm{cm}$.

is comparable to the field strength used in other plant cell transformation systems $[6,11,15]$. The plasmid DNA concentration of $100 \mu \mathrm{g} / \mathrm{ml}$ was sufficient for routine measurement of the CAT activity. The effect of the field strength on the CAT expression in the licorice protoplasts with linearized and supercoiled DNA forms is shown in Table 1.

The concentration of the pDNt-CaMV35Scat-nosNPT-1I plasmid used during electroporation was an important factor influencing the transient CAT activity in the licorice suspension protoplasts. The addition of $0,20,50$, or $150 \mu \mathrm{g} / \mathrm{ml}$ of the carrier DNA to the licorice protoplasts (in the presence of 0 , 50 , or $100 \mu \mathrm{g} / \mathrm{ml}$ of the plasmid DNA) did not cause any increase in the CAT expression (Table 2).

From the results presented in this paper, it is apparent that the transient CAT expression in the licorice suspension protoplasts depends on two categories of parameters: 1) the use of a rectangular pulse generating system and electroporation optimized protocol have given as a simple and effective approach for the CAT reporter gene activity in electroporated protoplasts, and 2) the maximal transient CAT expression depended on the physiological characteristics (after enzymes treatment) of the freshly isolated licorice protoplasts.

Thus, the licorice suspension protoplasts contained many large starch granules and these suspension cells were highly cytoplasmic. The successful of the plasmid penetration in the electroporated suspension protoplasts were depended from the electroporation conditions, and when relative optimum of low field strengths and long pulse duration was applied. It is possible that such combination of electrical parameters induces more pores in the plasma membrane, allowing more plasmid DNA to be taken into the nucleus; or perhaps a longer pulse duration facilitates the electrophoretic movement of the plasmid DNA molecules to the nucleus.

The level of transient CAT expression (percent conversion of chloramphenicol to its acetylated products) were very similar to the results obtained for the suspension of sorghum, wheat, bean, sugar beet and conifer plant species [19-23].

The pulse generator has delivered RC pulses, the duration of which was under precise control.

These results demonstrated that the highest CAT activity per $10^{4}$ surviving suspension protoplasts was obtained at $350 \mathrm{~V} / \mathrm{cm}$, when the linearized plasmid of $100 \mu \mathrm{g} / 1$ concentration was used (a mean of $72 \mathrm{CM}$ ).

Similarly, using the linearized plasmid DNA resulted in higher levels of the transient expression as compared to the supercoiled DNA. Higher transformation efficiency with the linear plasmid DNA has been reported for bacteria, yeasts, filamentous fungi, protoplasts and intact tissue $[6,8,14]$. Due to the inner twist of the molecule and the absence of the double helix distortions, the linear plasmid DNA is highly mobile in the electric field. Macromolecular movement across pores is facilitated when the molecules are linear because the absence of tertiary and quaternary structures reduces their volume and allows 
Table 3

Flavonoids production in electroporated licorice suspension cells (4 weeks of culture)

\begin{tabular}{|c|c|c|}
\hline 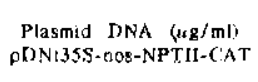 & Field strength, $V / \mathrm{cm}$ & $\begin{array}{l}\text { Total fiavonoids content. } \\
\% \text { (calculated on the } \\
\text { dry weight) }\end{array}$ \\
\hline
\end{tabular}

$\begin{array}{ccc}0 & 0 & 2.8 \\ 50 & 200 & 3.3 \\ 50 & 250 & 4.2 \\ 50 & 350 & 5.2 \\ 50 & 400 & 5.9 \\ 100 & 200 & 8.3 \\ 100 & 250 & 10.3 \\ 100 & 350 & 14.8 \\ 100 & 400 & 14.2 \\ 100 & 450 & 9.7\end{array}$

a more uniform superficial polarization to be induced by the electric field $[17,22]$.

The transient nature of both membrane pores and structural alterations in the cell wall, induced by the electric field, imposes conformational restrictions on the type of macromolecules which can be introduced to the cell.

The linear DNA has been found to be better than the circular one for the plasmid intake and integration, leading to the increased gene expression; and these results were shown with various important plant species $[6,19,21,22]$. We have also found that, in order to obtain high expression level, the licorice protoplasts must be prepared from rapidly growing suspension culture cells.

The increase in the cell wall permeability to DNA depended on the treatment of the licorice suspension culture cells with the pectolytic enzymes at the concentration of $0.5 \%(\mathrm{w} / \mathrm{v})$.

Furthermore, the CAT expression can be enhanced by these pectolytic enzymes treatment. Our data indicate that this effect, at least in part, may be due to the breakdown of cell clumps into smaller aggregates, in which a larger proportion of cells may be permeabilized, and presumably to the removal of pectin from the wall itself. The cold pretreatment of the suspension protoplasts and cell lines is known to be important for the achievement of the highest degree of electroporation and the protoplast viability after electroporation.

The electroporated cell lines were transferred into the modified MS medium with the addition of phytohormones, such as $\mathrm{BA}-0.5 \mathrm{mg} / 1$ and NAA $0.2 \mathrm{mg} / 1$. The level of flavonoids production was studied in the cells electroporated at various electric field strengths. The amount of flavonoids in the electroporated cell lines (Table 3 ) increased by 1.2 to 2.0 times, as compared to the control (non-electroporated cells) and depended on the field strenght and from the root-specific promoter ( $\mathrm{pDN} 23$ ) and which regulate the process in secondary metabolites production pathways. The highest level of flavonoids production $(14.8 \%$ ) was found in the licorice cells electroporated at the field strength of $350 \mathrm{~V} / \mathrm{cm}$.

Our results have shown that the optimized protocol for protoplasts isolation and the optimal electroporation conditions are important for the transformation rates of the licorice species. The movement of plasmid penetration into a freshly isolated protoplasts by electroporation occurs by electrophoresis through pores formed in the membrane by the electrical breakdown of the cells membrane. With a highly viable suspension protoplasts, the membrane breakdown is reversible. A good indicator to assess the suitability of a particular licorice protoplasts preparation for electroporation is yield. Only isolations suspension protoplasts yield exceeded $1 \cdot 10^{7}$ per gram fresh weight of suspension-cultured cells were used.

In our experiments, we have used plasmid with utilized the double $35 \mathrm{~S}-\mathrm{pDNt}$ (root-specific) promoters. The root-specific promoter is suitable for the increase the total flavonoids production in electroporated licorice cell lines.

Further investigation is needed to determine the factors which cause an increase in intracellularly stored secondary metabolites production, especially in the cell lines culture.

Besides, the optimal mode of electroporation of the licorice protoplasts plays important role too.

After three weeks of incubation the protoplasts were transferred to the fresh modified MS medium. Subsequently this material was treated with fungal extract (FB) obtained from Acremonium sp., endophyte mycorrhizal fungus, and diluted before the use to $10^{-5}$ per 11 of medium. This homogenate of an Acremonium sp., fungal strain has been shown to be an effective elicitor for the total flavonoids production in the suspension culture of $G$. glabra. To achieve the maximum stimulation of flavonoids synthesis, we have used combination with the other elicitor as a yeast extract (YE) added to the nutrient medium at the concentration of $500 \mathrm{mg} / 1$. The electroporated suspension licorice cells were additionally treated with these both biotic elicitors on the time prolong period as 1 week. Than, these treated cell lines were transferred on the fresh medium. Such elicitated procedure could stimulate obtaining maximal level (as 
Table 4

Flavonoids production in electroporated $(350 \mathrm{~V} / \mathrm{cm})$ and elicited licorice suspension cells ( 4 weeks of culture)

\begin{tabular}{l|l|c}
\hline Passage number & $\begin{array}{c}\text { Elicitors for the } \\
\text { protoplasts trekiment }\end{array}$ & $\begin{array}{c}\text { Total favonoida containe, \% } \\
\text { calculated on the dry weight }\end{array}$ \\
\hline Control ${ }^{*}$ & Non elicited & 2.7 \\
1 & Yeast extract (YE) & 15.3 \\
2 & Fungal bioextract (FE) & 17.8 \\
3 & YE + FE & 18.3 \\
4 & YE & 14.9 \\
5 & FE & 16.1 \\
6 & YE + FE & 19.1 \\
\hline
\end{tabular}

${ }^{*}$ Control — non-electroporated celis.

high as $19.1 \%$ of dry weight) of the total flavonoids production on the 28 th day of culturing. Both the elicitors doses and the age of electroporated protoplasts to be elicited needed to be optimized. The optimal time for elicitor addition may be specific to the elicitor and the culture system, in general it was in the mid- to late exponential-growth phase.

The existence of an optimal dose may suggest that, at elicitor doses smaller than the optimum, the elicitor-binding sites in the electroporated cells were still not fully utilized for activating the flavonoids synthesis, while excessive doses caused a deleterious effect on the suspension cells biosynthetic activity. However, it is still not well understood how these elicitors mediated the pathway of the flavonoids biosynthesis in electroporated plant cells. These responses may include the synthesis and incorporation of hydroxyproline-rich glycoproteins, cellulose and polymers, the production of phytoalexins, and the enhanced expression of gene encoding enzymes such as phenylalanine ammonium-lyase and which is a general in flavonoids biosynthesis pathway. To further improve the effect of the fungal elicitor on flavonoids production, we may need to use more purified of the fungal homogenate. Furthermore, the dosage, timing and frequency of elicitation and the medium renewal strategy should be optimized systematically.

It has been shown in several reports [24-28 ], that the use of yeast and fungi as elicitors provokes accumulation of phytoalexins. In our system with the licorice electroporated cells the biggest effect on the flavonoids production was obtained in the modified MS medium with both elicitors; the percent of viable cells was $78.3 \pm 3.3 \%$ as compared to the control cell lines (the same medium, but without elicitors) was $67.3 \pm 4.1 \%$.

Many previous studies have shown positive effects the some elicitors on a variety the important secondary metabolites as well too $[25,26,28]$.

When elicitors, bioextract from fungus Acremonium sp. and YE, were used, total flavonoids content increased 2-5 times (Table 4).

Experiments are now aimed at the obtaining of stable transformation and subsequent cell proliferation of the licorice protoplasts and at the selection of the transformed over-productive cell strains in the medium with these elicitors.

In summary, the results presented in this paper demonstrate the first example of direct gene transfer in suspension protoplasts of the licorice cells as well as describe electroporation conditions for successful transient gene expression and flavonoids production from electroporated suspension cells.

\section{II. Г. Коваленко}

Транзієнтна генетична експресія в електропорованих суспензійних протопластах солодцю Glycyrrhiza glabra L. і іхній вллив на вихід флавоноїдів

\section{Резюме}

Суспензійні протопласти солодцю Glycyrrhiza glabra L. мрансформуваги химерною плазмідою рDNt23-CaMV35S-nos методом електропорації, для чого було підібрано оптимальні параметри цього прочесу. Експресію підтверджуєали за допомогою репортерного гена хлорамфеніколацетилтрансферази (САT). Максимальна його активність у трансформованих клітинах солодки спостерігалася через 50 год. Отримані трансформовані клітинні лініі продовжували культивувати протягоя місяця для визначення сумарної фракції флавонойдів. Трансформовані клітинні агрегати солодцю додатково обробляли біотичними еліситорами Вміст флавоноїдів в оброблених клітинних агрегатах у $2-5$ разів перевинував контроль.

\section{П. Г. Коваленко}

Транзиентная генетическая экспрессия и накопление флавонокдов в электропорированных суспензионных протопластах солодки Glycyrrhiza glabra L.

\section{Резюме}

Суспензионные протопласть солодки $G$. glabra L. трансформировали методом әлектропорации химерной птазмидой рDNt23 CaMV35S-nos, для чесо были подобраны оптимальнье параметры этого процесса. Экспрессию подтверждали с помощью репортерного гена хлорамфениколацетилтрансферазы (СAT). Максимальная его активность в трансформированных клетках солодки наблюдалась спустя 50 ч. Полученные трансфор мированные клеточные линии продолхали культивировать в течекие месяца для определения суммарной фракции флавоноидов. Трансфорнированные клеточные агрегаты солодки дополнительно обрабатывали биотическими элиситорами. Содержание флавоноидов в обработанных агрегатах в $2-5$ раз превынало контроль.

\section{REFERENCES}

1. Aoki T., Akashi T., Ayabe S. Flavonoids of leguminous plants: structure, biological activity and biosynthesis $/ / \mathrm{J}$. Plant Res. $-2000 .-113 .-$ P. $475-478$ 
2. Kovalenko P. G., Antonjuk V. P., Maliuta S. S. Secondary metabolites production from transformed cells of Glycyrrhiza glabra and Potentilla alba as a producents of radioprotective compounds // Ukr. bioorg. acta.-2002, -1, N 1,-P. 21-31.

3. Li W., Asada Y., Yoshikawa T. Antimicrobial flavonoids from Glycyrrhiza glabra hairy root cultures // Planta Med.1998.-64.-P. 746-747.

4. Christie S., Walker A. F., Lewith G. T. Flavonoids - a new direction the treatment of fluid retention // Phytother. Res.2001.-15.-P. 467-475.

5. Hamil J. D., Parr A. J., Rhodes M. J., Robins S. R., Walton $N$. J. New routes to plant secondary productst $/ / \mathrm{Bio} / \mathrm{Technol}$ ogy. $-1987 .-5 .-$ P. 800-804.

6. Shillito R. D. Saul M. W., Paszkowski J., Muller M. Potrykus $I$. High efficiency direct gene transfer to plants // Bio/Technology. - 1985.-3.-P. 1099-1103.

7. Murashige T., Skoog $F$. A revised medium for rapid growth and bioassays with tobacco tissue cultures // Physiol. Plant.1962.-15, N 3.-P. 473-479.

8. Widholm J.M. The use of fluorescein diacetate and phenosafraine for determing viability of cultured plant cells // Stain Technol.-1972.-6.-P. 189-194.

9. Доманский Н. Н., Генине Л. В., Коваленко П. Г., Медведева Т. В., Газарян К. Г., Галкин А. П. Клонирование фрагмента ДНК табака, обладающего свойствами промотора в трансгенном растении // Молекуляр. биология.1985.-23, № 5.-C. $1391-1399$.

10. Gorman C. M., Moffat L. E, Howard B. H. Recombinant genomes which express chloramphenicol-acetyltransferase in mammalian cells // Mol. Cell. Biol._-1982._-2._-P. 10441051 .

11. Jones $H$, Ooms $G$., Jones $M$. Transient gene in electroporated Solanum protoplasts // Plant Mol. Biol.-1989.-13. P. 503-511.

12. Бандюкова B. A. Фотоколориметрические методы определения флавоноидов // Материалы 1-го Всерос. съезда фармацевтов.-М.: Медицина, 1964.-.С. 227-230.

13. Георгиевский В. П., Комисссаренко Н. Ф., Дмитрук С. E. Биологически активные вещества лекарственных растений.--Новосибирск: Наука, 1990.--328 с.

14. Gallois $P$., Lindsey $K$, Malone $R$. Electroporation of tobacco leaf protoplasts using plasmid DNA or total genomic DNA // Meth. in Mol. Biol.-New Jercy: Humana Press Inc, 1995.P. 89-95.

15. Kovalenko P. G., Schuman N. V., Ponomarenko S. $P$ Biotechnological advances of electroporation of grapevine and sugar beet cells // Bioelectrochem. and Bioenerg. - 1997.43.-P. $165-168$.
16. Rathus $C$., Birch $R$. Optimization of conditions for electroporation and transient expression of foreigh genes in sugarcane protoplasts // Plant Sci.-1992.-81._-P. 65-74.

17. Bekkaouti $F$. Datha $R$. S., Pilon $M$. The effects of promoter on transient expression in conifer cell lines // Theor. and App!. Genet. - 1990.-79.-P. 359-363.

18. From $M$., Taylor $L$., Walbot $V$. Stable transformation of maize after electroporation // Nature.-1986.-319.-P. 791-793.

19. Dillen W., Engler G., Montagu M. V., Angenon G. Electroporation-mediated DNA delivery to seedling tissues of Phaseolus vulgaris L. (common bean) // Plant Cell Rept.1995.-15.-P. 119-124

20. Zhou H., Stiff C., Konzak C. Stably transformed callus of wheat by ectroporation-induced direct gene transfer // Plan1 Cell Rept.-1993.-12, N 4.-P. 612-616.

21. Laursen C., Krzyzek R., Flick C., Anderson P. C., Spencer T $M$. Production of fertile transgenic maize by electroporation of suspension culture cells // Plant Cell Rept.-1994.-24.P. $51-61$.

22. Lee T., Turgeon $R$., $W_{u} R$. Expression of a foreign gene linked to either a plant-virus or a Drosophila promoter, after electroporation of protoplasts of a rice, wheat, and sorghum // Proc. Nat. Acad. Sci. USA. -1986. -83. - P. 6815-6819.

23. Симоненко Ю. В., Кучук Н. В. Генетическая трансформация гороха посевного (Pisum sativum L.) методом електропорации протопластов // Физиология и биохимия культ. растений.-1999.-31, № 3.-P. 203-207.

24. Srinivasan $V$., Ciddi V., Bringi $V$., Shuler $M$. Metabolic inhibitors, elicitors and precursors as tools for probing yield limitation in taxane production by Taxus chinensis cell cultures // Biotechnol. Progr.-1996.-12.-P. 457-465.

25. Donenburg $H$., Knor $D$. Strategies for the improvernent of secondary metabolite production in plant cell cultures // Enzyme Microb. Technol.-1995.-17.-P. 674-684.

26. Flores-Sanchez I. J., Ortega-Lopez J., Montes-Horcasites C. Biosynthesis of sterols and triterpenes in cell suspension cultures of Uncaria tomentosa // Plant Cell Physiol. - 2002. 43, N 12.-P. 1502-1509.

27. Yoon I. L., Kim H. K., Ma C. J., Huh H. Induced accumulation of terpenoids in Scutellaria baicalensis suspension cultures using a yeast elicitor // Biotechnol. Lett. - 2000.22.-P. $1071-1075$

28. Ignatov A., Clark W., Cline S., Psenak M., Krueger R. J., Coscia $C . J$. Elicitation of dihydrobenzophenanthridine oxidase in Sanguinaria canadensis cell cultures // Phytochemistry.1996.-43.-P. $1141-1144$

УдК $575.22: 581.143 .6$

Надійшла до редакції 20.02.03 